Vol. VII, Fasc. 1 e 2 , p. $3-28$.

\title{
ON SOME PROSOBRANCHIA FROM THE COAST OF SÃO PAULO
}

(Received 19-9-957)

Eveline du Bois-Reymond Marcus

(Caixa postal 6994, S. Paulo)

(with 4 plates)

In the following I give the descriptions and discussions of some remarkable Prosobranchs collected while my husband and I studied Opisthobranchs on the coast of São Paulo. The first belongs to a peculiar genus of the Neritacea, the second to the Lamellariacea not yet recorded from Brazil. I add some morphological observations on Ianthina, a genus that has been made accessible taxonomically by the monograph of Laursen (1953).

I am sincerely grateful to the Royal Danish Academy of Sciences which presented us with a copy of Bergh's first monograph of "Marseniaderne" (1853) and to Privatdozent Dr. Sebastian A. Gerlach (Kiel) for the photographs of Bergh's principal work on the Lamellariacea (1886b; 1887). I am also indebted to Dr. Henning Lemche and Dr. Dan Laursen (Copenhagen) for the Dana-Report on Ianthina, and to Dr. Harald A. Rehder (Washington, D. C.) for excellent copies of papers on North American species of Lamellaria.

Some of the collecting trips on which the mollusks were obtained have been subsidized by the National Research Council of Rio de Janeiro.

\section{CONTENTS}

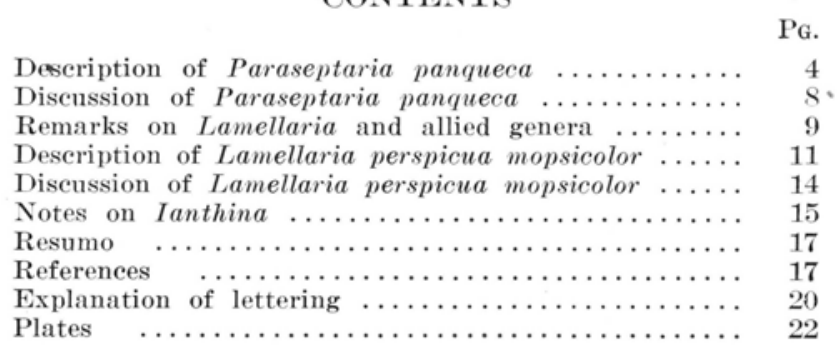


Description of Paraseptaria panqueca sp. n.

(Fig. 1-11)

The cap-shaped shell is up to $6 \mathrm{~mm}$ long, 4,5 $\mathrm{mm}$ broad, and about $2 \mathrm{~mm}$ high. The apex is flat, directed to the right, and lies a little in front of the posterior border. Hence the anterior, convex slope occupies more than $5 \mathrm{~mm}$, the posterior, slightly concave one less than $1 \mathrm{~mm}$ of the total length. The side slopes are nearly straight. The colour of the periostracum varies from light straw to dark rust. Its rough surface has a pattern of radiating ribs and concentric lines whose crossings bear salient knobs. On the anterior slope the growth lines divide and increase in number. The calcareous shell has an almost smooth surface which shows concentric darker and lighter lines. These are considerably narrower than those of the periostracum, but increase on the anterior slope too.

The aperture has the same extent as the shell, because it is not restricted by any parietal area. The horseshoe-shaped muscle scar is open in front. The inner surface is porcellaneous.

In the living slugs (Fig. 1) the slender tentacles and the pointed foot protrude from under the shell, and peg-shaped papillae $(e i)$ on the mantle border stand out. These papillae or pallial tentacles bear a tuft of cilia on their tip and contain groups of subepidermal sensory cells. The under surface of the mantle is provided with a uniformly broad band of high glandular epithelium ( $\mathrm{mi}$ ) with erythrophilous secretion. The eyes lie in the bases of the tentacles; the mouth is flanked by flat lobes whose ventral margin is accompanied by a narrow band of cilia, continuous in front. The foot $(0 o)$ is separated from the head by a deep fold. The anterior border of the foot is square and has a transverse furrow; the creeping sole is even.

The operculum (Fig. 3) comprises about 1,3 whorls and is entirely internal, enclosed in an epithelial sac connected with the dorsal epidermis of the foot by a thin tube. The triangular operculum is composed of a colourless central part $(e c)$ which is calcareous and spiral and a broad, brown, corneous outer part. The central part is provided with an apophysis. The calcareous centre occupies half of the total breadth $(0,6 \mathrm{~mm})$ of the operculum; the height of the operculum is $0,42 \mathrm{~mm}$.

The right and left shell muscle $(m)$ are of equal size. They are, contrary to Septaria (Bourne 1908, f. 2; Yonge 1947, f. $31 \mathrm{H}$ ) united behind; this caudal union is distinctly thinner than the lateral bands.

On the sides of the foot, at about the middle of its height, there is a ridge $(w e)$ underlain by a vessel $(u)$ and extending from the head to the middle of the body. This epipodial fold is better developed on the right side, where its dorsal epidermis is ciliated $(o c)$ in both sexes. The ciliated area begins near the hind end of the right fold and extends forwards to the entrance of the mantle cavity ( $\mathrm{ma}$ ). Here it turns inwards around the retractor of the foot onto the floor of the mantle 
cavity, and ends opposite to the genital opening (ge) which lies in the roof. Presumably the cilia of the right epipodial fold produce an outgoing current, so that the faeces are carried back behind the exhalant opening (Yonge 1947, p. 476). A few subepithelial sensory cells were observed in the epipodial fold of the present species, not in Hydrocena cattaroensis (Thiele 1910, p. 352), where the epipodial ridge is longer but located as in our species.

The mantle cavity is deep. Near its entrance, on the left side, lies the simple, not folded, osphradium (o) which is $0,7 \mathrm{~mm}$ long, rather narrow, and a little broader in front. It is identical with the "Mantelsinnesorgan" of Cinnalepeta (Thiele 1902, p. 327 f. 17, 18) and the "subpallial sensory organ" of Septaria (Bourne 1908, p. 829 fig. 15). In some specimens the osphradial epithelium forms a concavity, in others it is flat. The ctenidium $(q)$ arises from the roof in front of the fundus, and has, as in other Neritacea (Bourne 1908, p. 831), no skeletal rods. There is no vestige of a right ctenidium. Over the free end of the gill the glandular band of the mantle border $(\mathrm{mi})$ extends onto the roof of the mantle cavity and forms a blue-staining glandular area $(\mathrm{ji})$ which we consider as hypobranchial gland. On the right side of the cavity the rectum ( $r c)$ projects from the roof with a long papilla which ends with the anus $(a)$. Thus the faecal pellets are led near to the opening of the pallial cavity. Farther inwards the genital openings (ge) are located in the roof without a papilla.

What was seen of the nervous system in three dissected snails and five series of sections agrees with Bourne's description (1908, p. 852-860) which includes the older observations.

The middle-sized cerebral ganglia stand far apart from one another (Fig. 5). They are connected by a thick dorsal cerebral $(n)$ and a thin ventral subcerebral or labial commissure. Outgoing anterior nerves supply the surroundings of the mouth, farther backward ones the tentacles and the oral lobes. The nerves to the eyes have a common root with those to the tentacles. The eyes are subepidermal, closed vesicles with a lens and a vitreous body. The statocysts (st) lie between pleural $(p u)$ and pedal $(p i)$ ganglia and contain numerous small statocones. The buccal ganglia (bi) are voluminous and connected by a short distinct commissure. The cerebro-pleural and cerebro-pedal connectives are very long.

Though the pleural ganglia lie over the pedal ganglia, they show separated in the sections (Fig. 8). The independence of the subintestinal from the right pleural ganglion is even less pronounced than in Bourne's Neritina (1908, f. 36). The right pleural ganglion is a little bigger than the left, and a rather thick subintestinal root of the visceral loop is present. The supra-intestinal nerve is extremely fine already where it leaves the dorsal surface of the right pleural ganglion. As in other Neritidae and the Hydrocenidae (Thiele 1910, p. 352) the pleural and pedal commissure together form a ring. The further pleural nerves, viz. the cephalic, anterior pallial, branchio-pallial-osphradial, and columellar nerves were observed; the branchio-pallial-osphradial ones are 
thickest. Also the origin of the opercular nerves from the pedal ganglia was seen.

Commissures between the pedal cords occur in our species; they are rare and vary individually. They are not coated with nervecells as are the cords; the few nuclei around the commissures belong probably to their connective sheaths.

The visceral commissure shows a right and a left-hand swelling. From the right the genital ganglion is given off. The left-hand enlargement was followed to the renal pore; its connection with the supra-intestinal ganglion and to the osphradium, verified by Bourne, was not found, probably it is very thin. The long osphradial ganglion and its nerve from the left pleural ganglion were traced.

The mouth is surrounded by 3-4 rows of long epithelial papillae. As generally in the Neritacea (Bourne 1908, p. 827, 852) there is one unpaired cartilage (cr) under the radula and three pairs of buccal cartilages. The smallest pair $(c a)$ lies in front and to the sides. The following pair (ce) is the biggest; its anterior horn consists of numerous small cells. Two smaller cartilages (ci) cap the hind ends of the big ones.

The long radula (Fig. 7) consists of $80-100$ rows and is similar to that of the other Neritidae (Baker 1922). The central tooth is rectangular, twice as broad as it is long, and bears a smooth cusp nearly in its middle, which occupies the whole breadth of the tooth. The first lateral or intermediate tooth is approximately as broad as the central tooth. It has a big cusp on its posterior or under side, five to six denticles on the anterior side, and a broad spine near its base. The second lateral tooth is small; it lies between the cusp and the denticles of the first, has a knob near its base, and ends with a point. The third lateral tooth is bigger than the second, of irregular shape, and provided with some minute denticles. The high fourth lateral tooth has a narrow base and a shovel-shaped cusp which has five broad outer denticles and an inner auricle. There are 67-70 hook-shaped, about $0,08 \mathrm{~mm}$ long marginal teeth (uncini) whose cusps have 6 outer and 4 inner pointed denticles. The number of the latter diminishes towards the outer end of the row.

The folded glandular pouches $(s a)$ of the other ancient gastropods (Thiele 1902 , p. 341), which Risbec (1955, p. 47) regards as incipient salivary glands, open into the beginning of the oesophagus $(e)$ and unite under the radular sac. The oesophagus bends first to the left; this is considered as a trace of the larval torsion (Bourne 1908, p. 827). The narrow oesophagus is of equal width on its entire length and has a variable number (6-15) of longitudinal folds. Near the end of the visceral cavity it enters the stomach from the right side together with three hepatic ducts $(l)$. The stomach $(s)$ is lined with cilia in front and to the right, while it bears a cuticle behind and to the left. The cuticle is underlain by cells containing granules, as in Hydrocena cattaroensis (Thiele 1910, p. 354). The pyloric part or mid-gut $(p)$ begins 
on the anterior right side of the stomach as a soft, folded, wide tube. Gradually it becomes thinner and passes into the intestine $(g)$, in whose massy contents diatoms are the only recognizable elements. The long intestine forms several coils and runs to the right side of the mantle cavity, where the anus (a) lies on a high papilla far in front of the genital openings $(g e)$.

The intestine pierces the ventricle (he) excentrically. A minute right auricle (ar) lies behind the ventricle as in Septaria (Bourne 1908 , p. 833). As in this genus (1. c., p. 832) the branchial vein receives blood from a large pallial sinus $(u)$ at the point where the vein enters the left auricle. Evidently the pallial blood lacunae obtain oxygen through the roof of the pallial cavity. The pericardium $(p c)$ is ample. From the level of the left auricle (ae) the renopericardial duct (re) goes to the right. It passes under the left outer part of the kidney $(k)$ and opens into the right inner renal portion. The duct is thin and lined with very numerous and long cilia. The kidney is a rather uniform U-shaped sac with some lobes which are attached to the intestine and touch the genital duct $(v)$. Its smooth lining consists of vacuolized cells in both limbs. Only near the renal pore (ro) there is a small area of narrow ciliated urethral cells. Also the slit-like pore is clothed with high ciliated cells. In one of our five series of sectioned specimens this region of the nephropore contains numerous gland cells filled with granular erythrophilous secretion, as Bourne (1908, p. 864 f. 47) has found in Neritina (Vittoida) variegata Less.

The follicular testis ( $t i)$ lies over the digestive gland (liver) in the hind part of the visceral cavity. The tubular male duct $(d)$ begins fine. It forms some loops, and in its further course is distended by sperm, acting as a seminal vesicle, as in Theodoxus fluviatilis (Fretter 1946, p. 313). The vesicle enters the prostatic part (no) from the left side and from below. The broad prostatic duct is richly folded and ciliated, its under side is covered with glandular tubes which produce erythrophilous secretion. The outer part of the male duct has no glands, it forms only two folds which are separated by a tongue-shaped process (di) of the dorsal wall of the duct. This process projects from the genital opening (Fig. 10). Contrary to Theodoxus (Fretter 1946, p. 315) and other neritids there is a considerable distance between the genital aperture and the seminal groove. The latter begins dorsally to the right tentacle with a densely ciliated area of the cephalic epidermis and is continued into the deep ciliated groove along the dorsal side of the penis, a small peg-shaped outgrowth (pe) under the right tentacle. The rest of the penial epithelium is not ciliated. The penis is provided with strong longitudinal muscle fibres and a thick nerve.

The ovary $(o v)$ occupies the same position as the testis and is also follicular. The female duct (oi) runs forwards. Its wide glandular folds constitute the mucus gland and include the albumen gland. In a young specimen the glandular cells hang in clusters from the outer suriace of the ciliated duct. From the glandular portion the nidamental duct $(v)$ narrows towards the genital aperture. Separated from the 
latter only by a fold lies the vaginal opening, from which the wide and folded vagina $(v a)$ goes backwards. Close to the vaginal entrance a muscular sac $(b u)$ originates from the vagina. This sac is empty in the sectioned three females. It is the bursa copulatrix or spermatophore sac. Farther inwards the vagina is connected to a receptaculum seminis ( $r s)$ by a short stalk. The receptaculum is muscular and lined by a high epithelium with enormous cilia. In it the spermatozoa lie orientated with their heads to the wall. The inner continuation of the vagina leads to the fertilization chamber or vestibule (Fretter 1946, p. 315) which communicates with the oviduct. There is no "glande du calcaire" (Risbec 1942, p. 24), crystal or reinforcement sac (Andrews 1937 , p. 527), maybe in correlation with the great distance between nidamental opening and anus.

Occurrence: Seven males and eight females under stones at the coast of Ilhabela, near low water-line; June and July 1956. One male under stone at Ubatuba; June 1957.

\section{Discussion of Paraseptaria panqueca}

Risbec (1935, p. 410) had first allocated his Septaria (Paraseptaria) parva Risbec (1942, p. 36) to Cocculina and called the shell "patelliform" and resembling that of Acmaea. Hence it can be taken for granted that the shell has no parietal area, thought the description and the figures are omissive with regard to this character. The absence of a parietal area or "Spindelfläche" separates Paraseptaria generically from Septaria, actually isolates it from all other genera of the Neritidae or even excludes it from this family. Paraseptaria is an independent genus, not a subgenus of Septaria, and therefore the old Navicella parva Mousson 1849, to-day Septaria parva (see Van Benthem Jutting 1953, p. 282), does not invalidate Paraseptaria parva Risbec.

Septariellina Bequaert and Clench (1936, p. 163) has a shell quite different from that of Paraseptaria.

While Risbec's species is well established by the combination of external operculum and wanting parietal area, the new specific name for panqueca remains problematic. It does not belong to Phenacolepas Pilsbry 1891, which combines a shell without parietal area with absence of the operculum. Two species of the warm-water region of the Western Atlantic Ocean, Acmaea hamillei P. Fischer (1856, p. 276-277; Crosse 1872 , p. $145-146$ t. 5 f. 6 ) and Scutellina antillarum Shuttleworth (Dall 1889 , p. 342 t. 31 f. 10,11 ) have been transferred to Phenacolepas, as far as I see, without explicit statement of the wanting operculum. $P h$. hamillei has been recorded (Lange de Morretes 1949, p. 63) from a locality near where we found Paraseptaria panqueca. The radula of $P h$. hamillei has, as far as I know, not been described; that of antillarum is similar to that of panqueca. 
Certainly Phenacolepas hamillei and Ph. antillarum can no longer be ascribed to Phenacolepas, if they are found to have an operculum. In this case, hamillei might prove to be identical with panqueca, while antillarum differs by not denticulated cusps of the uncini.

The quite posterior position of the apex, and the external, corneous operculum without apophysis distinguish parva, perhaps even generically, from panqueca; minor differences are the shape of the first and fourth lateral and the marginal radular teeth.

Paraseptaria can, at least provisionally, be allocated to the Neritidae, though some of its characters differ from those indicated in Thiele's diagnosis of this family (1931, p. 71-72). These are: the absence of a columellar (parietal) area, the not-stalked eyes, the epipodial ridge, and the kidney not divided into an excretory part and a bladder. As long as the anatomy of the type-species is not better known, it is not desirable to introduce a new family for Paraseptaria.

\section{Remarks on Lamellaria and allied Genera}

Thiele (1931, p. 265-266) unites all Lamellariids without marginal teeth of the radula in one genus with four sections, while I prefer Bergh's system $(1886 ; 1886 a)$, of course with the necessary modifications of some names. The male duct is separated from the visceral cavity by a layer of transverse muscles in Coriocella Blainville 1824, while it runs freely in the body cavity in Lamellaria Montagu 1815, and Marseniella Bergh 1886. Marseniella (see Bergh 1887, p. 251 t. X, f. 1, 2) differs from Lamellaria by characters of the shell and details of the gut. A weak calcification of the shell however is not a generic character of Marseniella, as it occurs in Lamellaria too, e. g. L. leptolemma Bergh (1899, p. 31), L. verrucosa Odhner (1924, p. 31) and others (Odhner 1926, p. 35).

The characters indicated for Djiboutia Vayssière (1912, p. 121) seem to me rather specific than generic ones. The symmetrical legs of the median tooth make it probable that Vayssière's species verrucosa belongs to Lamellaria, not to Coriocella, where these legs generally are of unequal size (Bergh 1905, p. 113, note 1). As Lamellaria, Vayssière's verrucosa (non Odhner 1924) must receive a new name.

Coriocella is Indo-west-Pacific with one doubtful exception: Lamellaria patagonica Smith (1881, p. 32) from the Strait of Magellan has been transferred to Coriocella due to its shells (Bergh 1887, p. 285). The legs of the radular middle tooth, however, are of equal size in Smith's species. Later on (1905, p. 112) Bergh identified with patagonica a female from the Fiji--Islands, whose middle tooth, size, and sculpture make it probable that it really belongs to Coriocella, but its identity with Smith's species is not sure. According to Bergh (1886b; 1908), Vayssière (1912, p. 118), and Melvill (1918, p. 142) nigra Blainv., tongana (Q. G.), berghi (Desh.), and semperi (Bgh.) are indubitable species of 
Coriocella; possibly the two first are one and the same species. of the further species described as Coriocella or Chelyonotus, tuberosa Stimpson (1853, p. 378), patagonica Bergh (1905, p. 112), and malayica (Boettger 1918, p. 132) probably belong to Coriocella, while punctata Stimpson (1. c.) can not be judged.

Lamellaria is a cosmopolitan genus. The classification of its species must be based exclusively on morphological criteria, because the geographic distribution of some species is of great extent. L. diegoensis (Bergh 1886b, p. 172; 1887, p. 248), for example, whose author is Bergh, not Dall as generally written, occurs off South California ("uncommon offshore" Abbott 1955, p. 175) and on the coast of Tasmania (Bergh 1905 , p. 110). L. perspicua (L.) is recorded from the Faroes and the Norwegian coast to the Azores (Bergh 1892, p. 30) and the Mediterranean, on the African coast from Cape Verde to the Cape Province (Bergh 1907, p. 104; Odhner 1923, p. 25), and in the Indic-west-Pacific Ocean from French Somaliland (var. ceryle Bergh 1899, Vayssière 1912, p. 115) to the Gulf of Siam (Bergh 1902, p. 213), the Aru Islands (Bergh 1908 , p. 105), and the Japanese Sea (Bergh 1905, p. 110). The records of $L$. perspicua from the Western Hemisphere are scarce (Odhner 1923). Several times shells have been found in the stomachs of fishes caught on the coast of Massachussetts (Gould 1870, p. 337), but, as Odhner (1913) has informed, these shells belong to Marsenina glabra Couthouy 1832. Dry Tortugas, Florida (White 1952, p. 106), Valdéz Peninsula, Argentina (Bergh 1894, p. 223), and Strait of Magellan (here also three varieties, Bergh 1898, p. 564-568) are valid American occurrences of L. perspicua.

Most of the other South American Lamellariidae from the Magellanic district are more or less questionable. The above-mentioned $L$. patagonica Smith with Vandyke-brown lines and spots on the back can possibly be recognized, when new material is obtained in the Strait of Magellan. Lamellaria hyadesi, courcellei, and dozei Rochebrune \& Mabille (1891, p. 35 t. 3 f. 8, 9), however, can not be identified. Also Lamellaria fuegoensis, ampla, elata, and magellanica Strebel (1906, p. 145-147), of which only the shells were described, will remain "species incertae sedis". The, well-drawn sigaretus antarcticus and S. praetenuis Gould (1852, p. 216, 217; 1856, t. 15 f. 259, 260) from Orange Harbour, Hoste Island may belong to Lamellaria or to Marseniopsis. A widely distributed species of the latter genus (Bergh 1898, p. 570) occurs in the Magellanic district and the Gulf of Ancud. The Peruvian province is not included in the present discussion.

Several Central American species of Lamellaria must be compared with the new form from the coast of São Paulo, as far as it is possible without the knowledge of their radulae. L. fernandina Dall (1927, p. 119) from deep water off Northern Florida has a shell half as big as that of my species, only two and a half whorls, and a closed columella ("axis imperforate"). L. cochinella Perry (1940, p. 80) off Sanibel Island, Florida, differs from the species of São Paulo by brilliant scarlet colour and smooth notum. Besides the shell of $L$. cochinella is higher and has 
a smaller aperture (Perry \& Schwengel 1955, t. 47, f. 326) than the Brazilian material. Also in the two other Floridan species, L. leucosphaera Schwengel (1942, p. 62, t. 3, f. 8; Perry \& Schwengel 1955, t. 47, f. 327) and $L$. koto Schwengel (1944, p. 17-18, t. 1, f. 3-6, 6a; Perry \& Schwengel 1955, t. 47, f. 328) the aperture occupies less of the length of the shell than in the Brazilian form. L. rangii (Bergh 1853, p. 94) from St. Thomas, Virgin Islands, has been named but not described. The characters that separate the present form from the typical perspicua are mentioned in the discussion following the description.

The North American Lamellariids that occur north of Cape Hatteras, Lamellaria pellucida Verrill 1880 (Bergh 1886b, p. 168; 1887, p. 239) and $L$. pellucida var. gouldii (ibid. p. $169 ; 241$ ) differ from my form by their entire, not bifurcate, base of the median radular tooth. This group is restricted to the Atlantic Ocean (Odhner 1926, p. 34-35).

\section{Description of Lamellaria perspicua mopsicolor, f. $n$.}

(Fig. 12-21)

Three males and four females, all with reproductive organs, were gathered in the tidal zone of the coast of São Paulo, namely at Guarujá near Santos, at Ilhabela, and near Ubatuba. The snails were found among weeds and under stones in April 1954, June and August 1956, and November 1953 and 1955. One further female was collected by Dr. Diva Diniz Corrêa in July 1957 at Cabo Frio (Lat.: 22 $57^{\prime}$ S., Long.: $42^{\circ} 1^{\prime}$ W.), under a stone in the tidal zone. On all these localities Ascidiacea are frequent, for example, Didemnidae on the algae and Botryllidae under stones. An intimate relation however between the snails and compound ascidians, which is known elsewhere (Bergh 1886b, p. 157158; Ankel 1935; 1936, p. 178; Fretter 1946, p. 324) was not verified, nor was it on the coast of New South Wales (Allan 1950, p. 137). Our two biggest snails measured alive are males, the third male is smaller than the biggest female. These few data may be casual; in other species of the genus the males are smaller than the females (Bergh 1887, p. 246; Ankel 1936, p. 157). Contrary indications exist for Coriocella berghi (Bergh 1886b, p. 222) and typical L. perspicua (Bergh 1887, p. 228).

Our snails were up to $15 \mathrm{~mm}$ long alive, about $10 \mathrm{~mm}$ broad and $7 \mathrm{~mm}$ high. The dorsal surface is provided with soft, large bosses, about ten on one transverse level. The living snails are rather transparent light brown, with numerous white and dark dots or rays (the female from Cabo Frio). Dark centres of the bosses surrounded by a ring of white dots, make the aspect of the snails similar to certain Didemnids. The black pigment of the roof of the mantle cavity shines through the skin. Yellow glands and greyish-red tints were noted in the living animals. The foot is white with yellow spots. The preserved snails are uniformly grey or have spots of black pigment, and the white granules of the skin are dissolved. 
The flat, auricular shell is thin, but completely calcified, transparent in life, and white in preserved state. The periostracum is colourless, the growth lines are slight. The apex is hardly prominent. The flattened shell consists of two to three whorls, the first of which is that formed in the larva. This nuclear whorl is smoother and purer white than the following ones which begin in some specimens with a slight depression. The whorls increase rapidly in size, and the body whorl is very wide. Through the large aperture the apex can be seen from below. The parietal wall bears a crescentshaped thickening. A preserved $9 \mathrm{~mm}$ long male has a $7 \mathrm{~mm}$ long, $5 \mathrm{~mm}$ broad and $2 \mathrm{~mm}$ high shell. The shell of the female from Cabo Frio is $8 \mathrm{~mm}$ long and $6 \mathrm{~mm}$ broad. This snail that was $10 \mathrm{~mm}$ long preserved may alive have been the biggest of our material.

The shell is produced by the glands which encircle the bottom of the shell chamber. Two bundles of muscle fibres connect the shell with the muscles of the foot; the left bundle runs farther in front than the right one.

The under side of the mantle is provided with a dense net of blood sinuses (Fig. 19, $u$ ) and powerful muscles. This disposition may be of respiratory function or stiffen the mantle border protectively, when the snail contracts. The dorsal epidermis is slightly thicker than that of the under side; it contains also numerous blood lacunae and glands. The entire upper ridge or "lip" of the anterior pedal groove is studded with eosinophilous glands which open into the groove. Besides a $0,1 \mathrm{~mm}$ long epidermal tube runs inwards from the centre of the groove. This is the outlet of pale pink glands which form a loose cluster comparable to those of Onchidiopsis glacialis (Bergh 1887, t. V, f. 28). These glands extend $0,4 \mathrm{~mm}$ backwards.

The central nervous system agrees with Bergh's figures (1886, f. 1; $1886 \mathrm{~b}$, t. R, f. 2 ; 1899 , t. 1 f. 10 ). The nerve ring lies, together with the oesophagus, to the left of the middle, as in Marseniopsis conica (Eales 1923, p. 24). The supra-intestinal ganglion is situated on the left pleural ganglion, the subintestinal ganglion on the foliate stomach. The pedal ganglia are the most voluminous ganglia and stand out in front of and behind the nerve ring. Also in the series of transverse sections the secondary ganglia (ganglia succenturiata, Simroth 1899, p. 398), which are intimately connected with the pedal ganglia, appear as first elements of the central nervous system, and the posterior nerve-cells of the pedal ganglia are the hindmost. In this respect Bouvier's figure of typical Lamellaria perspicua copied by Simroth (1899, f. 97) and Thiele (1925, f. 43) differs from the present form. Zygoneury occurs on both sides (Bergh 1892, p. 30). The connective between the supra-intestinal ganglion and the right pleural ganglion is not missing, contrary to what Plate (1922, p. 455) supposed, but an abdominal (visceral) ganglion (ibid., f. $45, v$ ) is not set off.

The eyes are of the common type in Monotocardia, vesicles with lens. The latter is made up of concentric layers and almost touches the rods; a vitreous body does not stain. 
The statocysts lie near the pedal ganglia and contain a single statolith. The sensory epithelium is surrounded by a capsule of connective tissue, but so extense discs, as described and drawn by Bergh (1886, p. 169 f. 1) and mentioned by Simroth (1899, p. 325) and Ankel (1936, p. 138) were not verified in the dissected or sectioned slugs of the present form.

The bipectinate osphradium (o) has 20-30 leaflets of somewhat unequal length on both sides of the axis. The 38 leaflets of the ctenidium (q) are nearly smooth in the male (Fig. 20), more folded in the female (Fig. 21). The length of the branchial leaflets is $1,4 \mathrm{~mm}$, the base 0,6 $\mathrm{mm}$ in the male, and 2,1 and 1,3 in the female. Hence the respiratory surface of the female is more than thrice that of the male.

The muzzle is everted like a proboscis in several specimens. In these cases the dorsally fused jaws appear to the sides of the mouth; they are yellow in front, colourless behind, 0,77-1,2 $\mathrm{mm}$ long and 0,91-1 $\mathrm{mm}$ broad. Their anterior borders are more truncate than in typical L. perspicua. The radula consists of about 70 rows. As the teeth solidify but slowly, there is a number of incipient rows. The following teeth are yellow and the oldest colourless, an uncommon sequence. The legs of the central tooth are generally equal, though some slightly longer left legs occur. The cusp of this tooth has 3-6 denticles on the right side only. The lateral teeth have 3-5 denticles on the inner and 7-18, most frequently 9-12, denticles on the outer side. The two odontophoral cartilages are contiguous in front and diverge backwards.

The ciliated oesophagus $(e)$ swells into a wide crop $(c)$ which lies in front of the nerve ring as in Coriocella (Bergh 1886b, p. 213) and typical Lamellaria perspicua. The single diverticulum of the anterior gut lies behind the nerve ring in Marseniopsis (Eales 1923, f. 25). A second, transverse and voluminous sac, evidently Bergh's proventriculus or "zweiter Kropf", lay over the buccal mass and the anterior part of the foliate stomach in one of our dissected snails, but not in a second, nor in the sections. Though these observations are scanty, it seems that the second crop is a variable organ in the present form. Bergh indicated an inconstant occurence of the first crop in Coriocella and Lamellaria (1886b, p. 213; 1887, p. 233).

The foliate stomach $(f)$ or psalterium, Simroth's "jabot" (1901, p. 504), receives the oesophagus from the front. As drawn by Bergh (1886, f. 2), the oesophagus does not disappear in the foliate stomach, but continues through its entire length as a ciliated gutter $(h)$. The musculature of the foliate stomach is very thin. The organ is frail, nearly spongy; its lumen is filled with numerous folds of glandular epithelial cells. Mainly the ventral and lateral parts of the foliate stomach are wrapped in a flat mass of yellow glands $(i)$ which lie outside the muscle fibres. These glands form a loose epithelium around a narrow lumen and in some places a network of tubes. No communication with the gut was found, though it must be expected to exist. Bergh considered these glands as possible salivary glands, but could not see any connection 
with the anterior gut. Therefore Simroth (1901, p. 510) supposed that they were a part of the foliate stomach; but their position beyond the muscles of the latter does not favour this opinion.

At the hind end of the foliate stomach the oesophagus reassumes the regular shape of a tube and enters the digestive gland $(l)$. This encloses the true stomach $(s)$ and lies in the upper visceral cavity, the stomach quite to the left. The latter is provided with strong muscles. Along its right side runs the oesophagus. The cardia $(j)$ is located nearly in the middle of the stomach, and from here on the oesophageal cilia are substituted by the gastric cuticle. This lines the fundus and the middle part of the stomach, while it is dissolved into rodlets in the anterior, pyloric, region. Of the three wide tubular communications between stomach and digestive gland one $(y)$ lies on the level of the cardia, one $(z)$ behind and one $(x)$ in front of it.

The pyloric part of the intestine ( $p$ ) may still belong to the absorbent region, while the following three fourths $(g)$ contain faecal pellets. The only recognizable contents of the gut were a few nematocysts in the rectum; they are bigger than those of the Alcyonaria which were mentioned as food (1886a, p. 9; 1886b, p. 156).

The reproductive organs are well known by several papers of Bergh and by Fretter's study (1946). As Bergh (1886, p. 172; 1886b, p. 156) called the prostate "appendicular", and Simroth (1904, p. 615), even more explicitly, describes it as a blind tube, it may be mentioned that the prostate is a coiled, ciliated and glandular part of the male duct, as Fretter (1946, p. 321) already described it. The shape of the penis (pe) is variable.

On the whole, the aspect of our snails, which are taxonomically homogeneous, and the dimensions and the consistency of their organs, are rather varied.

\section{Discussion of Lamellaria perspicua mopsicolor}

The present form is allied to typical $L$. perspicua. The taxonomical value of the anatomical features, viz. the larger pedal ganglia, the less developed capsule of the statocyst, the dimorphism of male and female ctenidia, and the inconstant occurrence of the second crop cannot be estimated. Some of these characters must be examined in more numerous specimens, others are not known in typical perspicua. Central radular teeth constantly with denticles only on the right side have not yet been described in typical perspicua or any other species. An occasional unilaterally denticulate middle tooth has been reported and drawn several times in the literature, for example, in Coriocella nigra (Vayssière 1912, p. 120 t. 11 f. 167), C. berghi (Bergh 1886b, p. 224 t. S, f. 1), Lamellaria diegoensis (Bergh 1887, p. 250 t. T, f. 27), and Marseniella borealis (ibid., p. 253 t. V, f. 6). 


\section{Notes on Ianthina}

On July 7, 1956, my husband and I collected 21 living Ianthina on the beach at Ilhabela early in the morning after a stormy night with northern winds. Already in previous years we had found shells of the four species known from the Southern Atlantic (Laursen 1953), viz., I. janthina (Linné 1758); I. exigua Lm. 1816; I. prolongata Blainv. 1822, which Lange de Morretes (1949, p. 82) listed as Violeta globosa Swainson; and I. umbilicata d'Orb. 1840.

Fritz Mïller (1863) had called the species in which he discovered the spermatozeugmata I. pallida, but according to Laursen (p. 33) this species occurs only north of the equator. As Müller (p. 179) observed viviparity, his species was $I$. janthina.

Four ribbed specimens of the above mentioned 21 living snails were immediately recognized as $I$. exigua. The remaining 17 afforded some difficulties, firstly, because their shells were rather flat (ratio breadth: height from 1,22 to 2,0 with an average of 1,63$)$, while the flattest shell of Laursen (f. 15,7 ) has a ratio of 1,14 ( $I$. janthina). It is true that in the rich material of $I$. janthina examined by Wilson (1956) the ratio varies from 1,0 to 1,32, and the biggest shells (one inch) are the highest, while our samples are all much smaller, the biggest $18 \mathrm{~mm}$ in breadth. They approach figs. 11 and 14 on plate 3 of $I$. balteata and I. depressa respectively (Reeve 1858), which are both synonyms of $I$. janthina (Laursen p. 16). With the other species our shells do not agree at all, including I. pallida Thompson 1841. Unfortunately all our seventeen snails were in male phase, so that the principal character of $I$. janthina, viviparity, could not be verified.

As contribution to the open question of size and conditions of sex (Graham 1954, p. 1; Wilson 1956, p. 302) I mention, that my seventeen specimens had shells from $3,5 \mathrm{~mm}$ height and $5,5 \mathrm{~mm}$ breadth to $18 \mathrm{~mm}$ height and $14 \mathrm{~mm}$ breadth.

The male duct opens at the right side of the mantle cavity beside the rectum. According to Graham (1954) the genital duct acquires the female glands in the course of its transformation. But it does certainly not develop a new outlet as Laursen (p. 11) supposed for the oviparous species. Evidently Laursen (f. 4) has taken the deep glandular pouch of the sole for the outlet of the oviduct.

If the shell of my specimens is relatively broader than that of typical $I$. janthina, and their sexual phase does not allow for aplication of Laursen's key, the protoconchs of my material (Fig. 22) are even incompatible with Laursen's description (p. 14) and figure (f. 11) of the protoconch of $I$. janthina. As said, I have only semi-adult and adult shells available, while Laursen had veligers (f. 10) and very young stages (f. 11) as well. My specimens had been treated with alcohol. The structure of the vitreous protoconch consists of growth lines and some fine spiral lines; it is not "sculptured with small circles with a centre" as Laursen found it, possibly corroded by liquid or time. 
Without relation to the classification I report some anatomical features observed in the material of July 1956. Details seem to differ in the various species, so I indicate the species for each statement, for I. janthina however this name is used with the above-mentioned restrictions.

Simroth (1895, p. 6) and Laursen (p. 14) give eyes and statocysts as missing, while Thiele $(1928$, p. 75$)$ found rudimentary eyes in a species which is not named, but no statocysts (p. 77). The eyes of I. janthina and $I$. exigua lie underneath the muscle layer of the body wall. They are very small, as the diameter is 50 micra (janthina, Fig. 27 ) and 28 micra (exigua), that of the lens 28 micra (janthina) and 10 micra (exigua). They are however not rudimentary, because a cornea, a lens ( $c s)$, a pigmented retina ( $\mathrm{ra}$ ), and an optic nerve (ne) are present. The statocysts lie between the pedal ganglia and the retractors of the head, they contain one spherical otolith, 36 micra (janthina) and 20 micra (exigua) in diameter.

In $I$. janthina there are two pairs of pharyngeal glands which agree with the description of Risbec (1953, p. 199, f. 4, gbl, gsl) for I. globosa (according to Laursen: I. prolongata). The glands of the anterior pair (ai) are thin and smooth, white tubes with long and fine ducts opening (ia) ventrally under the jaw-plates. The posterior pair (si) is thicker, knobby, and black, it ends dorsally (ii) over the outer lamina of the buccal cartilage. The inner course of the white and the black glands is parallel, they coil around the hind end of the buccal mass. Thiele (1928, p. 77) described these two pairs with a common outlet on either side in his not-named species, while Risbec's indication of separate orifices in prolongata agrees with my statements for janthina. A third pair of pharyngeal glands was discovered by Thiele (ibid.) in his Ianthina and figured for Recluzia (cf. 2). Their serpentining whitish tubes (so) cluster along the lower border of the outer cartilaginous lamina (na) and run forwards and then upwards and open (io) into the dorso-lateral diverticles of the oral tube outside the jaw-plates $(j a)$. The contents of their glandular cells are granular, eosinophilous.

The radula $(30 \times 30.0 .30)$ of my $I$. janthina has teeth of very different aspects in each row (Fig. 26) so the difference can not be due to wear (Laursen 1953 , p. 19). The proportion of the distal part to the base varies from the innermost teeth with the 'shortest distal part to the marginal ones with the longest, hence the prong appears to lie differently far from the tip. The outermost teeth are rudimentary, and those in the middle of the half-row are very big. The developing teeth in the radular pouch $(r i)$ are reddish, the older ones farther forward are colourless.

The radular cartilages of my $I$. janthina and of $I$. exigua resemble those briefly described by Thiele (1928, p. 76) for his not-named species. The two cartilages ( $\mathrm{ni}$ ) which underlie the halves of the radula are prolonged at the hind end of the pharynx and folded to turn forwards outside the jaw-plates as outer laminae (na). The latter correspond to 
the outer cartilages of Simroth $(1895$, p. 10$)$ and to the membrane formed by large polygonal cells (Laursen 1953, p. 7), but each outer lamina is united with the inner lamina behind. Risbec (1953, p. 196) does not mention the posterior confluence of the outer and inner pair of cartilages in $I$. prolongata. He identifies the outer lamina with the jaw-plates, which he describes as "réticulum à polyèdres" covered with a "mince couche de consistence cornée". Only the latter is really the jaw-plate (ja), which is so homogeneous and colourless that it seems to have escaped Pruvot-Fol (1955, p. 306) who expected to find a strongly pigmented jaw.

I found the figures of the float of Ianthina so different from those of our $I$. janthina that I combined my sketches of the living snail in a drawing (Fig. 23). It reproduces the float as it appeared when the animals collected at the beach were brought into a dish with sea-water. The photograph of Dakin (1952, t. 63 7) refers probably to I. prolongata and is quite different; the photographs of Wilson (1956, f. 1-3) are similar to my sketches; his material was collected on the north coast of Cornwall and Devon and belongs to I. janthina.

\section{R E S M O}

Ao gênero Paraseptaria Risbec, 1942, baseado em P. parva Risb. da Nova Caledônia, foi atribuída $P$. panqueca, sp. n., do litoral de São Paulo. O gênero, sem área parietal (columelar) e com opérculo, externo em parva, interno em panqueca, reune caracteres das Phenacolepadidae e Neritidae, concordando o aparêlho feminino mais com o das últimas. $O$ opérculo interno da nova espécie sugere a possibilidade de terem sido atribuídas a Phenacolepas espécies não examinadas a respeito, p. e., Acmaea hamillei e Scutellina antillarum.

Lamellaria perspicua mopsicolor, f. n., da costa de São Paulo e do Cabo Frio, é a primeira espécie da subordem Lamellariacea verificada no litoral brasileiro. O ctenídio da fêmea é três vêzes maior que o do macho. Em seis exemplares, cuja rádula foi preparada, o dente central de tôdas as séries possui dentículos sòmente no lado direito da cúspide. Isto constitui o caráter principal da forma mopsicolor.

$\mathrm{Na}$ praia de Tlhabela as 4 espécies de Ianthina conhecidas do Atlântico meridional (Laursen 1953) são ocasionalmente arrastadas à praia: janthina, exigua, prolongata e umbilicata. Ûltimamente muitas conchas relativamente baixas de $I$. janthina foram encontradas, cujas protoconchas diferem, quanto à escultura, do material de Laursen. Nesta espécie e em I. exigua ocorrem olhos e estatocistos. I. janthina tem 3 pares de glândulas faríngeas, cujos dutos se abrem separadamente. $O$ aspecto dos dentes da rádula difere dentro da mesma série transversal, de maneira que a diferença não pode provir do gasto. As lâminas externas e internas das cartilagens bucais de $I$. janthina e $I$. exigua são unidas atrás da faringe; as mandíbulas homogêneas e incolores são estruturas independentes das cartilagens. Uma nova figura da balsa de I. janthina é apresentada (Fig. 23).

\section{REF ER E N C S}

ABBOTT, R. T. - 1955. American Seashells. XIV + 541 p., 40 t. New York (D. van Nostrand Company, Inc.).

ALLAN, J. - 1950. Australian Shells, etc. XIX + 470 p., 44 t. Melbourne (Georgian House). 
ANDREWS, E. A. - 1937. Certain reproductive organs in the Neritidae. Journ. Morphol. v. 61, p. 525-561, t. 1-6. Philadelphia, Pa.

ANKEL, W. E. - 1935. Das Gelege von Lamellaria perspicua. Zeitschr. f. Morphol. u. Oekol. d. Tiere v. 30, p. 635-647. Berlin.

- 1936. Prosobranchia. Grimpe \& Wagler, Tierw. d. Nord- \& Ostsee, part IX b 1, 240 p., 222 f. Leipzig (Akad. Verlagsges.).

BAKER, H. B. - 1924. Notes on the radula of the Neritidae. Pr. Acad. Nat. Sci. Phil. v. 75 (for 1923), p. 117-178, t. 9-16. Philadelphia, Pa.

BEQUAERT, J. \& CLENCH, W. J. - 1936. Rheophilous mollusks of the estuary of the Congo River. Mém. Mus. Roy. Hist. Nat. Belg. sér. 2 fase. 3, p. 161-168, t. 1. Bruxelles.

BERGH, R. - 1853. Bidrag til en Monografi af Marseniaderne. Dansk Vidensk. Selsk. Skr. 5. Raekke (Naturv. Math. Afdel. v. 3), 119 p., 5 t. Kjöbenhavn.

- 1886. Die Marseniaden. Zool. Jahrb. Syst. v. 1, p. 165-176. Jena.

- 1886a. Report on the Marseniadae. Rep. Voy. Challenger Zool. v. 15, p. $1-25$, t. 1. London.

- 1856b; 1887. Die Marseniaden. C. Semper, Reisen im Archipel der Philippinen. Malacol. Unters. IV. Th. Suppl. Heft 3 (18s6) p. 129-225, t. M-R; Heft 4 (1887) p. 227-285, t. S-AE. Wiesbaden.

- 1892. Opisthobranches provenant des campagnes du yacht l'Hirondelle. Rés. Camp. Scient. Albert I fase. 4, p. 1-35, t. 1-4. Monaco.

- 1894. Die Opisthobranchien. Part 13 of the reports of the dredging operation... by the "Albatross". Bul. Mus. Comp. Zool. Harv. v. 25 no. 10 , p. 125-233, t. 1-12. Cambridge, Mass.

- 1895. Die Opisthobranchier der Sammlung Plate. Faun. Chil. v. 1. Zool. Jahrb. Suppl. v. 4 fase. 3, p. 481-582, t. 28-33. Jena.

- 1899. Nudibranches et Marséniadés ... Princesse Alice. Rés. Cap. Sci. Monaco fasc. 14, p. 1-45, t. 1-2. Monaco.

- 1902. Gasteropoda opisthobranchiata. Dan. Exp. Siam Zool. Res. 1. Kgl. Danske Vid. Selsk. Skr. 6. Raekke (Naturv. \& Mathem. Afd. XII, 2) p. 159-218, t. 1-3, 1 map. Kjöbenhavn.

- 1905. Malacol. Untersuch. 6. Theil, 2. Lieferg. p. 57-116, t. 5-8. Wiesbaden.

- 1907. The Opisthobranchiata of South Africa. Tr. S. Afr. Phil. Soc. v. 17 part 1, p. 1-144, t. 1-14. Cape Town.

- 1908. Appendix zu den Prosobranchiata. Marseniidae. Siboga Exp. part 49 (1) a p. 104-107; part 50, t. 3, f. 18-19. Leiden.

BOETTGER, C. R. - 1918. Die von Dr. Merton gesammelten Wassermollusken. Abh. Senckenb. Naturf. Ges. v. 35 fasc. 2, p. 125-145, t. 8-9. Frankfurt a. Main.

BOURNE, G. C. - 1908. Contributions to the morphology of the group Neritacea of aspidobranch gastropods. Part I. The Neritidae. Pr. Zool. Soc. Lond. 1908 , p. 810-887, t. 46-66. London.

CROSSE, H. - 1872. Note complémentaire sur l'Acmaea Hamillei, Fischer. Journ. Conchyl. v. 20 (sér. 3 v. 12) p. $145-146$, t. 5 f. 6 . Paris.

DAKIN, WILliam J. - 1953. Australian Seashores. XII + 372 p., 99 t. Sydney \& London (Angus and Robertson).

DALL, W. H. - 1889. Report on the Mollusca ("Blake") II. Gastropoda and Scaphopoda. Bull. Mus. Comp. Zool. Harv. v. 18, p. 1-492, t. 10-40. Cambridge, Mass.

- 1927. Small shells from dredgings ... "Albatross". Pr. U. S. Nat. Mus. n. 2667 v. 70 , art. 18, p. 1-134. Washington, D. C.

EALES, N. B. - 1923. Mollusca. Part V. Anatomy of Gastropoda (except the Nudibranchia). Brit. Antaret. Exp. 1910 ("Terra Nova") Zool. v. 7 n. 1 , p. 1-45. London.

FISCHER, P. - 1856. Deseriptions d'espèces nouvelles. Journ. Conchyl. v. 5 (sér. 2 v. 1) p. $273-277$, t. 8 f. $8-9$, t. 11 , f. $7-10$. Paris. 
FRETTER, V. - 1946. The genital ducts of Theodoxus, Lamellaria and Trivia, ete. Journ. Mar. Biol. Assoc. Unit. Kingd. v. 26 (1947) n. ${ }^{\circ} 3$ (1946) p. 312-351. Cambridge.

GOULD, A. A. - 1852; 1856. U. S. Explor. Exp. v. 12 (Mollusca \& Shells). $\mathrm{XV}+510$ p.; Atlas: 52 plates. Boston \& Philadelphia.

- 1870. Report on the Invertebrata of Massachusetts, etc. 2nd ed. (W. G. Binney). V + 524 p., t. 16-27. Boston, Mass.

GRAHAM, ALASTAIR - 1954. Some observations on the reproductive tract of Ianthina janthina (L.). Proc. Malacol. Soc. Lond. v. 31, part 1, p. 1-6. London.

JOHNSON, C. W. - 1934. List of marine Mollusea of the Atlantic coast, ete. Pr. Bost. Soc. Nat. Hist. v. 40 (1934-1935) p. 1-204. Boston, Mass.

LANGE DE MORRETES, F. - 1949. Ensaio de catálogo dos moluscos do Brasil. Arqu. Mus. Paranaense v. 7, p. 5-216. Curitiba (Brazil).

LAURSEN, DAN - 1953. The Genus Ianthina. Dana Report n. ${ }^{9}$ 38, p. 1-40, 41 figs. and charts in the text, $1 \mathrm{t}$. Copenhagen.

MELVILL, J. C. - 1918. Deseriptions of thirty-four species ... Persian Gulf, ete. Ann. Mag. Nat. Hist. ser. 9 v. 1, p. 137-158, t. 4-5. London.

MÜLLER, FRITZ - 1863. Ueber eigenthümliche Gebilde in der Samenflüssigkeit von Janthina. Arch. Naturgesch. 1863 v. 1, p. 179-183, t. 10, f. 1-10. Berlin.

ODHNER, N. H. - 1923. Contribution to the marine molluscan faunas of South and West Africa. Göteb. Kungl. Vet. \& Vitterh. Samh. Handl. ser. 4 v. 26, n. 7 , p. 1-39, 1 plate. Göteborg.

- 1924. New Zealand Mollusca. Vidensk. Meddel. Dansk Naturh. Foren. v. 77, p. 1-90, 2 plates. Kjöbenhavn.

- 1926. Nudibranchs and Lamellariids from the Trondhjem Fjord. Kgl. Norske Videns. Selsk. Skr. 1926 n. ${ }^{\circ}$, p. 1-36, t. 1. Trondhjem.

PERRY, L. M. - 1940. A new Tellin of the subgenus Angulus, a new Lamellaria, etc. Nautilus v. 53, p. 79-81. Philadelphia, Pa.

PERRY, L. M. \& SCHWENGEL, J. S. - 1955. Marine Shells of the Western Coast of Florida. 198 p., 55 plates. Paleontological Research Institute Ithaca, N. Y.

PLATE, L. - 1922. Allgemeine Zoologie und Abstammungslehre. v. I, VI + 629 p. 557 f. Jena (G. Fischer).

PRUVOT-FOL, ALICE - 1955. Notes à propos de l'Acteon. Bull. Soc. Zool. France v. 80, n. ${ }^{\circ}$ 5-6, p. 301-307. Paris.

REEVE, A. L. - 1858. Conchologia Iconica v. 11. London.

RISBEC, J. - 1935. Biologie et pont de mollusques gastéropodes Néo-Calédoniens. Bull. Soc. Zool. France v. 60 n. 5, p. 387-417. Paris.

- 1942. Recherches anatomiques sur les prosobranches de la Nouvelle Calédonie (troisième partie). Ann. Sci. nat. Zool. sér. 11 v. 4, p. 21-83, 6 t. Paris.

- 1953. Note sur la biologie et l'anatomie de Janthina globosa (Gast. Prosobranches). Bull. Soc. Zool. France v. 78, n. 2-3, p. 194-201. Paris.

- 1955. Considérations sur l'anatomie comparée et la classification des gastéropodes prosobranches. Journ. Conchyl. v. 95, p. 45-82. Paris.

ROCHEBRUNE, A. T. \& MABILlE, J. - 1891. Mollusques. Miss, sci. Cap Horn v. 6 Zool. Part 2, p. 1-129, t. 1-8. Paris.

SCHWENGEL, J. S. - 1942. New Floridan marine mollusks. Nautilus v. 56, p. 62-66, t. 3 . Philadelphia, Pa.

- 1944. A new Floridan Lamellaria. Nautilus v. 58, p. 17-18, t. 1 f. 3-6, 6a. Philadelphia, $\mathrm{Pa}$.

SIMROTH, H. - 1896-1907. Gastropoda prosobranchia. Bronn, K1. Ordn. v. 3, 2. Abt., VII + 1056 p., 63 t. Leipzig (C. F. Winter).

SMITH, E. A. - 1881. Mollusca and Brachiopoda. A. Günther ... Zool. Collect. “Alert", etc. Pr. Zool. Soc. Lond. 1881, I, p. 22-44, t. 3-5. London.

STIMPSON, WM. - 1855. Descriptions ... marine Invertebrates from the Chinese and Japanese Seas. Pr. Acad. Nat. Sci. Phil. v. 7 n. ${ }^{\circ} 10$, p. 375-3S4. Philadelphia, $\mathrm{Pa}$. 
STREBEL, H. - 1906. Beiträge ... Molluskenfauna der Magalhaen-Provinz n. 4. Zool. Jahrb. Syst. v. 24 (1907) fase. 2 (1906) p. 91-174, t. 7-13. Jena.

THIELE, J. - 1902. Die systematische Stellung der Solenogastren und die Phylogenie der Mollusken. Zeitsch. wiss. Zool. v. 72 fasc. 2 \& 3, p. 249-466, t. 18-27. Leipzig.

- 1910. Ueber die Anatomie von Hydrocena cattaroensis Pf. Abh. Senckenb. Naturf. Ges. v. 32, p. 349-358, t. 25. Frankfurt a. Main.

- 1925. Prosobranchia. W. Kükenthal \& Th. Krumbach, Handb. Zool. v. 5 fase. 1, p. 40-94, f. 23-103. Berlin \& Leipzig (W. de Gruyter).

- 1928. Ueber ptenoglosse Schnecken. Zeitschr. wiss. Zool. v. 132, p. 73-94, 11 text figs. Leipzig.

- 1931. Handbuch der systematischen Weichtierkunde v. 1. VI + 778 p., 783 f. Jena (G. Fischer).

VAYSSIERE, A. - 1912. Recherches ... sur les Opisthobranches de la Mer Rouge, etc. Deuxième partie. Ann. Fac. Sci. Marseille v. 20 (1911-Suppl.) p. 5-158, t. 1-11. Marseille.

VAN BENTHEM JUTTING, W. S. S. - 1953. Annotated list of the non-marine Mollusea of the Molucean Islands Ambon, ete. Treubia v. 22, part 2, p. 275-318. Bogor (Java).

WHITE, K. M. - 1952. On a collection of molluses from Dry Tortugas, Florida. Pr. Malacol. Soc. v. 29, p. 106-120, t. 6. London.

WILSON, DOUGLAS P. \& M. ALISON WILSON - 1956. A contribution to the biology of Ianthina janthina (L.), Journ. mar. biol. Assoc. Un. Kingd. v. 35 n. ${ }^{\circ}$, p. $291-305$, t. 1. Cambridge.

\section{EXPLANATION OF LETTERING}
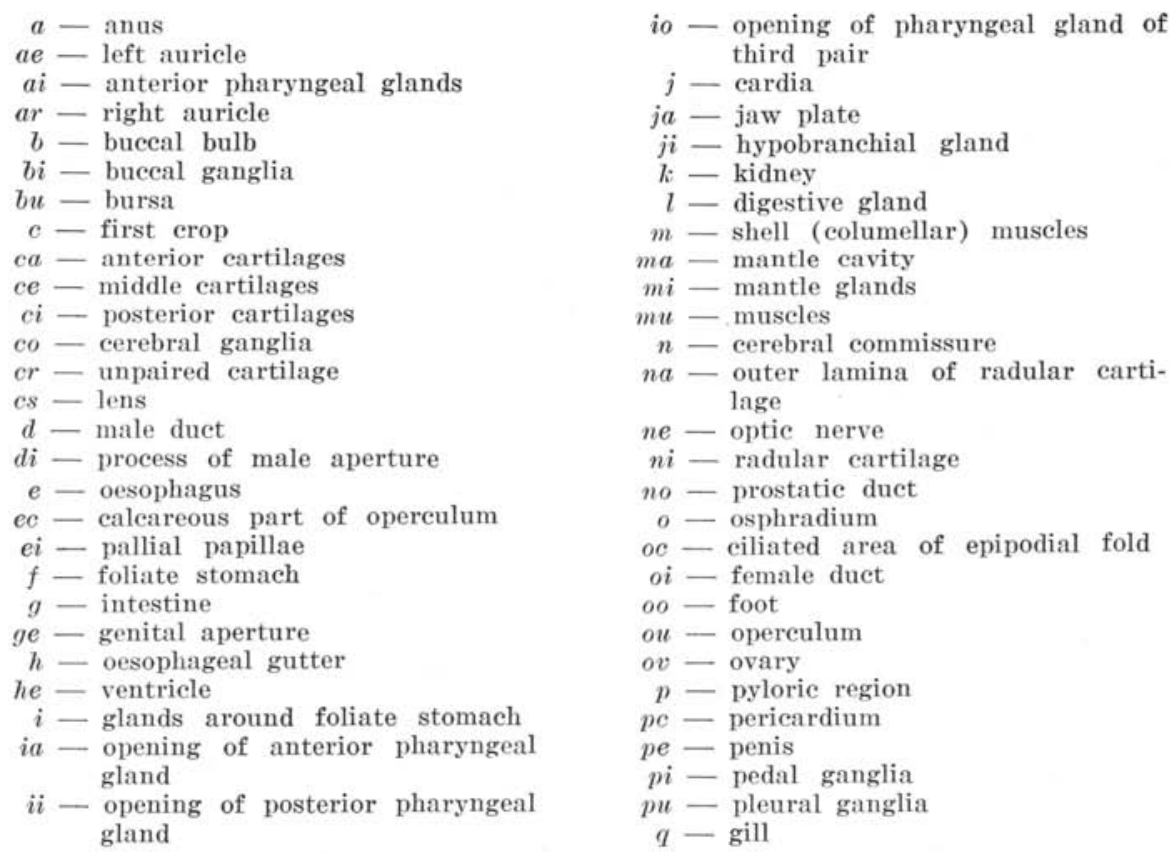


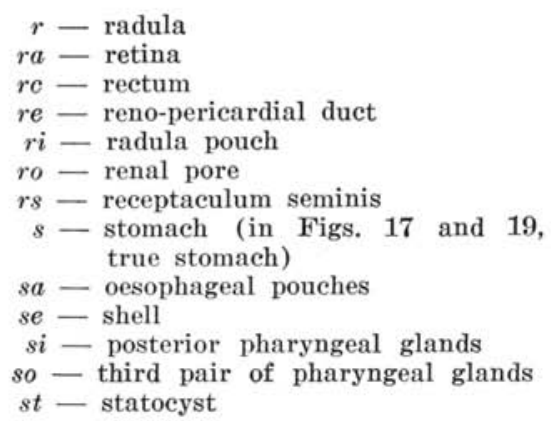

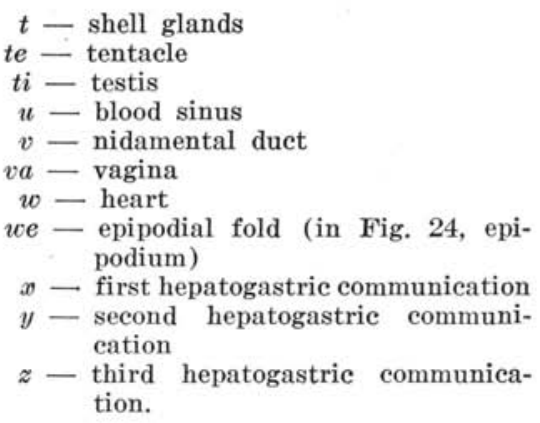


PLA TE 1

Paraseptaria panqueca, sp. n.

(see also plate 2)

Fig. 1 - Under side of living snail.

Fig. 2 - Lateral view of clarified snail.

Fig. 3 - Operculum

Fig. 4 - Dorsal aspect of anatomy.

Fig. 5 - Diagram of digestive tract; liver reduced.

Fig. 6 - Horizontal section of buccal cartilages.

Fig. 7 - Radular teeth. 


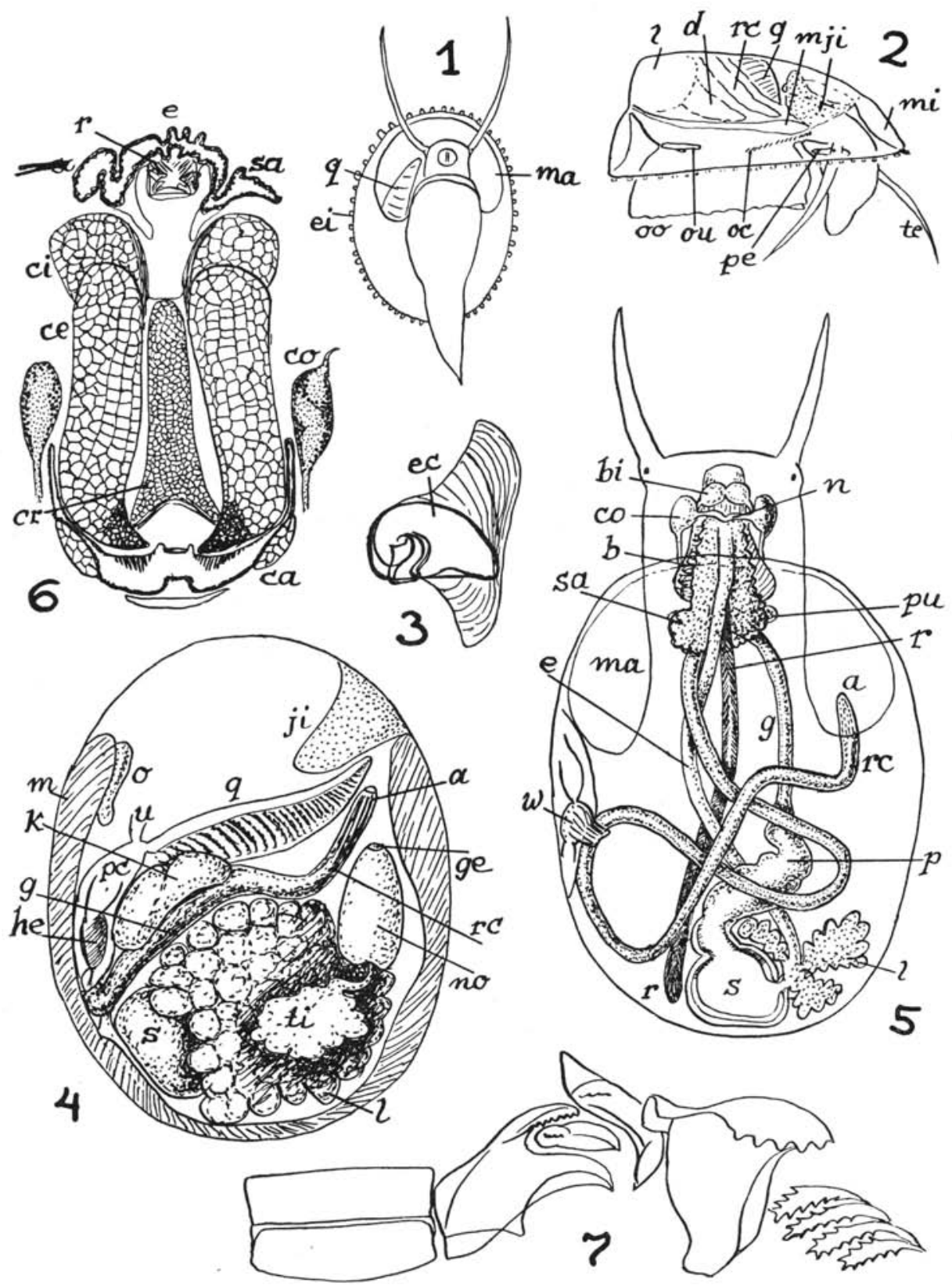




\section{PLATE 2 \\ Figures 8-11: Paraseptaria panqueca, sp. n. (see also plate 1)}

Fig. 8-Combined transverse section at level of gill.

Fig. 9 - Reconstruction of kidney and heart, dorsal view.

Fig. 10 - Male organs, rectum, and kidney, ventral view.

Fig. 11 - Reconstruction of female organs, dorsal view.

Figures 12-15: Lamellaria perspicua mopsicolor, f. n. (see also plate 3 )

Fig. 12 - Sketch of ereeping snail.

Fig. 13 - Shell from above.

Fig. 14 - Shell from below.

Fig. 15 - Shell seen from right side. 
E. d. B.-R. Marcus - Prosobranchia from S. Paulo

PLATE II

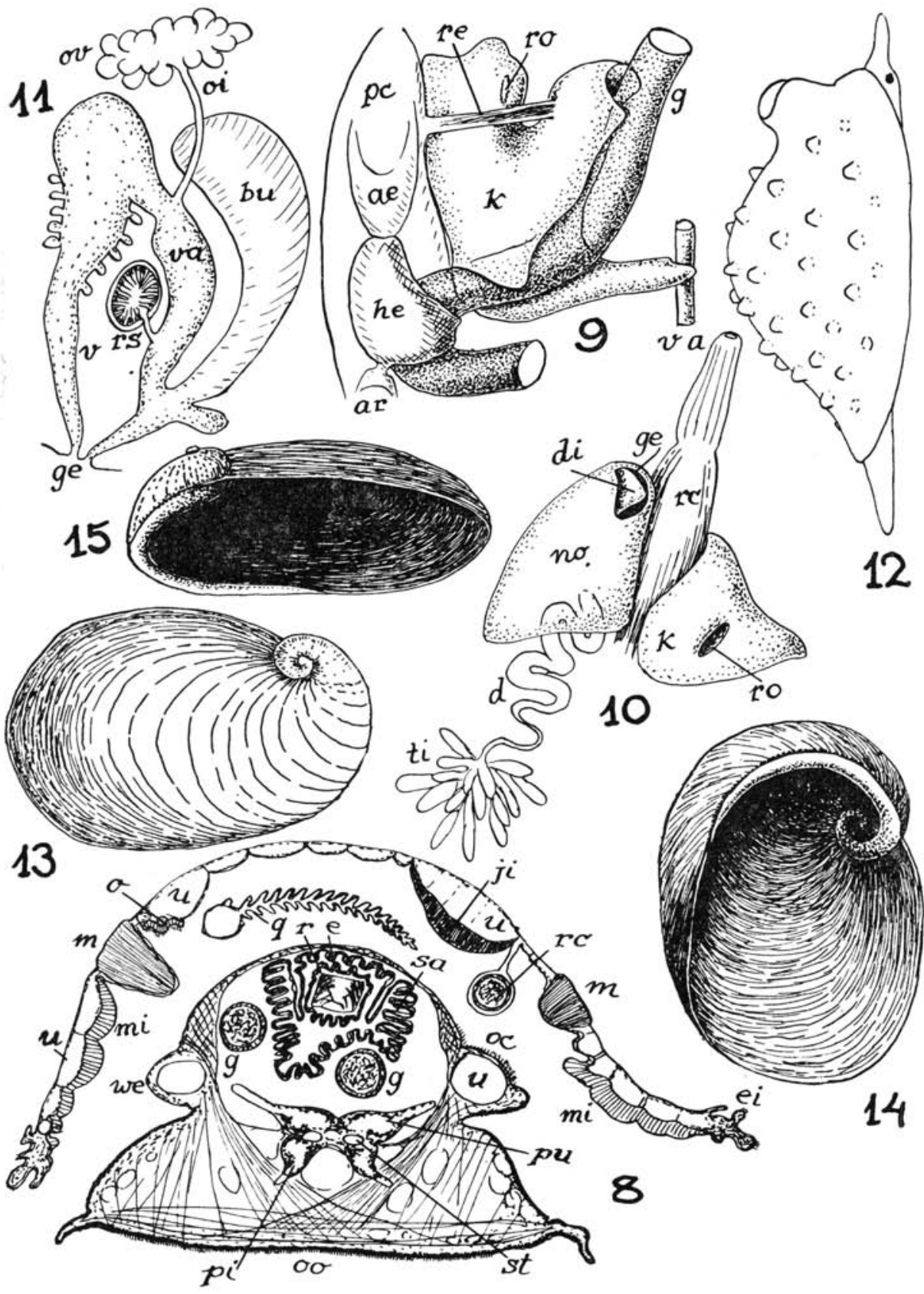




\section{PLATE 3}

\section{Lamellaria perspicua mopsicolor}

(see also plate 2)

Fig. 16 - Organization with roof of pallial cavity removed.

Fig. 17 - Diagram of alimentary tract.

Fig. 18 - Radular teeth.

Fig. 19 - Transverse section in middle of body.

Fig. 20 - Gill leaflet of male.

Fig. 21 - Gill leaflet of female. 


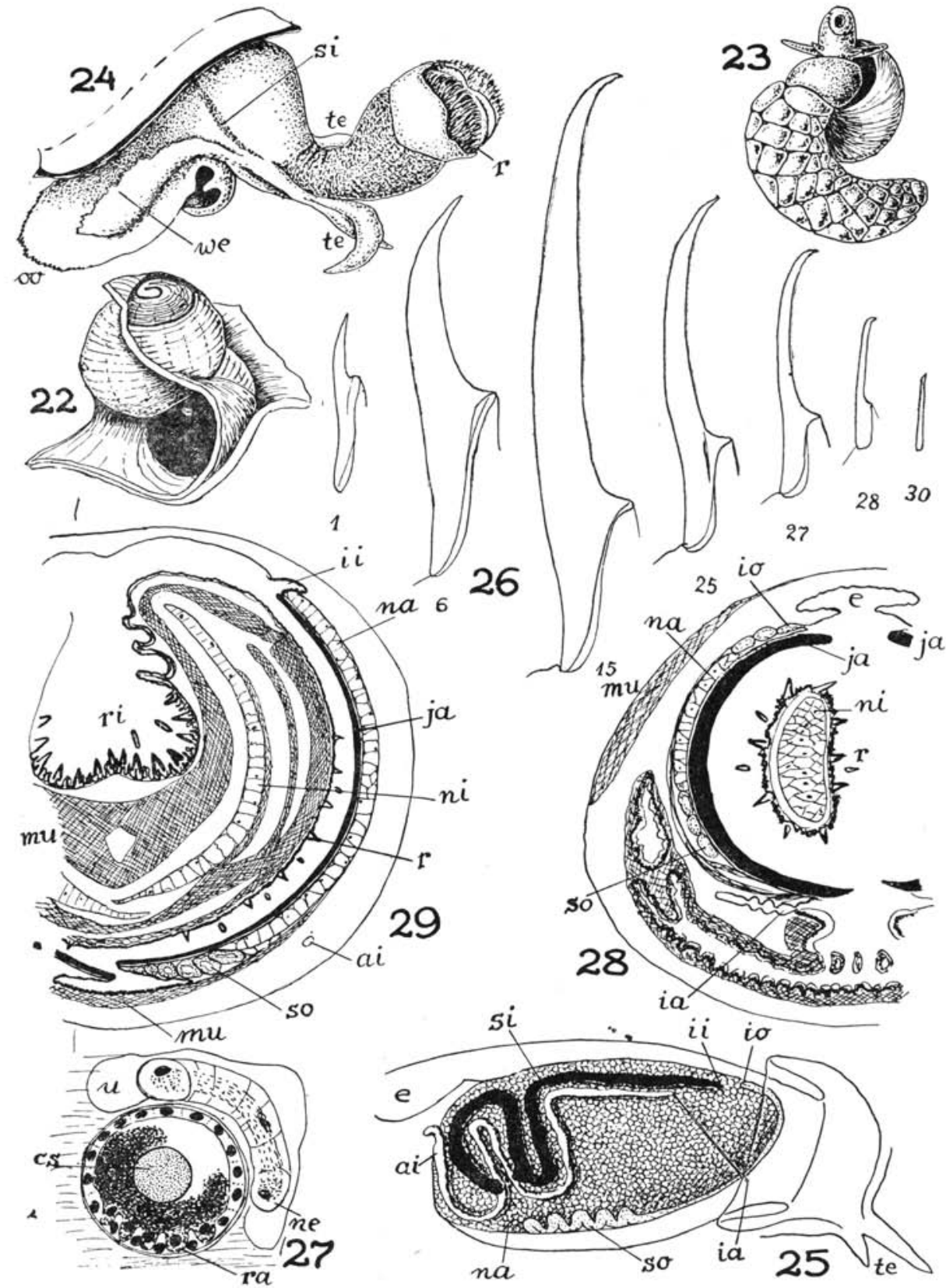




\section{PLATE 4 \\ Ianthina janthina (L.)}

Fig. 22 - Protoconch partly freed from shell.

Fig. 23 - Living snail with float.

Fig. 24 - Anterior part of preserved snail with everted proboscis.

Fig. 25 - Buccal mass with pharyngeal glands.

Fig. 26 - Teeth of one half-row of radula.

Fig. 27 - Section of eye.

Fig. 28 - Combined transverse section of buccal mass passing through opening of anterior pharyngeal glands and anterior ends of radular cartilages.

Fig. 29 - Same passing through openings of posterior pharyngeal glands. 


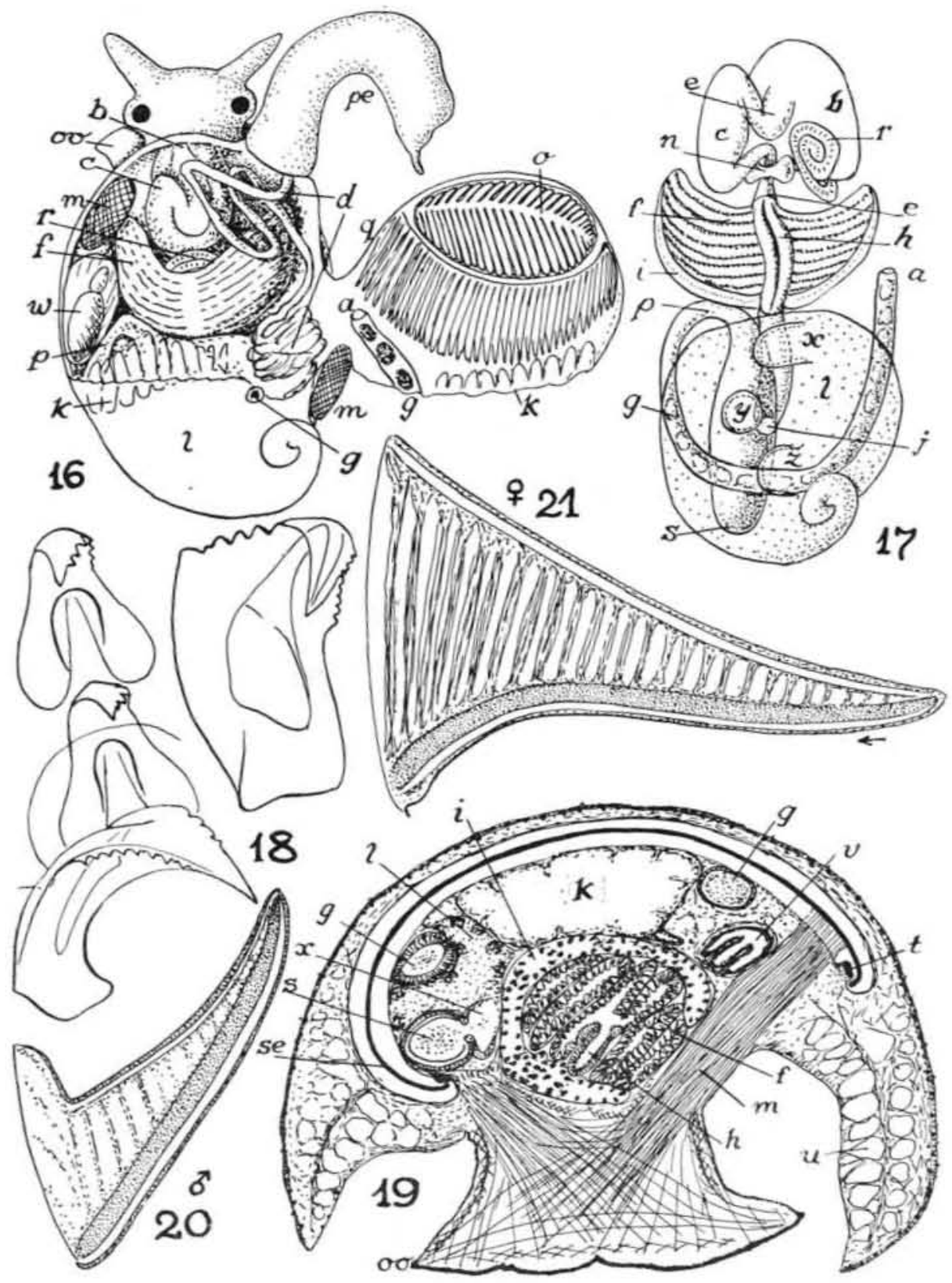

